\title{
The Study of Lisung-Halu as the Personification of Women in Mythical World In World View of Agrarian Sundanese
}

\author{
Tiara Isfiaty ${ }^{1}$, and Imam Santosa ${ }^{2}$ \\ 1. Doctoral Program of Art Science and Design, Institute of Technology Bandung, \\ Ganesha 10, Bandung 40132, Indonesia \\ 2. Doctoral Research, Faculty of Art and Design-Institute of Technology Bandung, \\ Ganesha 10, Bandung 40132, Indonesia \\ tiaraduana@gmail.com
}

Lisung berpasangan dengan halu adalah salah satu alat pertanian tradisional Sunda yang fungsinya untuk menumbuk padi menjadi beras. Dari perspektif pandangan dunia Sunda, lisung-halu adalah produk budaya yang lahir dari logika mitis orang Sunda. Manifestasi dari nilai-nilai, norma, karakteristik, keinginan dan kepercayaan Lisung-halu adalah personifikasi pria dan wanita dunia mitos. Orang Sunda berorientasi pada kesadaran akan asal usul mereka. Pria dianggap lebih kuat dari wanita. Namun dalam konteks lisung-halu, perannya menjadi terbalik. Artikel ini bersifat deskriptif kualitatif, menggunakan teori psiko-analisis dari Carl Gustav Jung untuk mempelajari fisik lisung-halu (kesadaran kolektif) sebagai personifikasi perempuan di dunia mitos (tidaksadaran kolektif) dalam kerangka pandangan hidup Sunda agraris. Pendekatan yang diambil dalam artikel ini adalah pendekatan budaya karena artikel ini merupakan upaya untuk memahami fakta yang merujuk pada sesuatu. Tulisan ini dalam rangka menghasilkan wawasan dan pengetahuan tentang nilai-nilai kehidupan dan kepercayaan orang Sunda agraris yang terkandung dalam lisung-halu melalui personifikasi perempuan di dunia mitos.

Kata kunci: wanita, dunia mitos, sunda agraris, lisung-halu

Lisung paired with halu is one of the traditional Sundanese farming tools that has a practical function as a pestle/grain pounder into rice. From the perspective of the world view of Sundanese, lisung-halu is a cultural product that is born from the mythical logic of Sundanese. It is the manifestation of the values, norms, characteristics, desires and beliefs of agrarian Sundanese. It is the personification of male and female in world's top (mythical world). Sundanese are oriented towards awareness of their origins. Men are considered stronger than women. But in the context of lisung-alu, the role becomes reversed. This article is descriptive qualitative by using the theory of psycho-analysis from Carl Gustav Jung to study the physical of lisung-halu (awareness output) as the personification of women in the mythical world (unconscious output) within the framework of the world view of agrarian Sundanese. The approach which is taken in this article is the cultural approach because this article is an attempt to understand the facts that refer to something. This writing is in order to generate insight and knowledge about the values of life and beliefs of the agrarian Sundanese which is contained in lisung-halu through the personification of women in mythical world.

Keywords : woman, mythical world, agrarian sundanese, lisung-halu

Proses Review : 1 - 28 Januari 2020, Dinyatakan Lolos: 10 Februari 2020 


\section{INTRODUCTION}

The article writing begins by the interest of the authors on the potential of local wisdom in the form of world view on tribes in Indonesia. There are so many cultural artifacts can be viewed as a medium that is full of local values of wisdom and knowledge. Indonesia is known as an archipelagic nation with its ethnic and cultural diversity. Each ethnic group will give birth and build on the characteristics of its respective values of life and beliefs. It presents as a local identity that distinguishes between one tribe with another. Sundanese is a term for the tribes in Indonesia who inhabit the western part of Java Island. As an agrarian society, Sundanese reflect their identity through values, norms, characteristics, desires and beliefs. It is translated through artifacts such as kidung/hymns, prasasti/inscriptions, dances even in the tools which are used daily as a symbol. According to Herusatoto in Mufrihah (2018 : 172) the symbol is an outward form containing purpose while the meaning is the content. One of the symbol that are closely related to Sundanese farming custom is lisung/ pestle and halu/mortar. The purpose of this study is to describe the Sundanese belief in rice, its derivatives and all its personifications, namely lisung-halu, based on archetype from Carl Gustav Jung theory.

Previous research on Sundanese lisung is very limited in number, and focus on the problems of lisung art. In addition, there is no Sundanese lisung study that based on the perspective of psychoanalysis. The literature about Sundanese culture is also limited. So this article has a novelty and is expected to contribute greatly to the perspective on artefact, as well as data base on track record of Sundanese. According to Soeganda in Traditional Ceremonies in Pasundan, lisung is derived from the word leles, which in Sundanese subtle languages means ngurut [1982: 170]. As a symbol, lisung has a particular form of presentation. The form of presentation according to Sumandiyo Hadi . in Mufriah (2018 : 172), is a physical form that shows an integral unity consisting of several interrelated components or elements and can be seen or enjoyed visually.

Sasmita in Traditional Technology Knowledge of Sundanese explains that lisung is a tool as a base when pestle or grain becomes rice, while halu is a tool to strike it [2014: 135]. Darpan in Kompendium The term of Sundanese Traditional Farming System explains besides lisung, urang/the people of Sunda uses wood jubleg or stone jubleg to pound rice. Generally lisung is in a rectangular shape/rectangle with a dimension in length of 6-10 m, width of 0.3-0.4 m and height of 0.15 to $0.25 \mathrm{~m}$. The best Lisung is made of striped wood, but generally it is made of jackfruit wood. Jubleg or also called pane or lulumpang, has two kinds of forms. First, it is cone-shaped which is cut off the tops [top diameter of $20-30 \mathrm{~cm}$, bottom diameter of $3-5 \mathrm{~cm}$, height of $16-20 \mathrm{~cm}]$. Second, is pyramid-shaped which is cut off the tops [top side of $26-30 \mathrm{~cm}$, lower side of $16-20 \mathrm{~cm}$, thickness of 2-3 cm]. Both lisung and jubleg are paired with halu in performing its functions to pound rice grain or rice. Halu is rounded [ $5-8 \mathrm{~cm}$ in diameter] and long [130-200 cm] with an oval-shaped tip. Generally it is made of guava tree, jengkol or peuteuy tree. Lisung-halu in the context of the structure of Sundanese culture, present as a medium of conveying the values, norms, characteristics, desires and beliefs of Sundanese.

Sundanese have an assumption that men are stronger than women. This is a form of Sundanese awareness of their origin. Referring to Warnaen, in the structure of Sundanese culture, boys are placed as human beings who are born on odd dates. Odd dates are considered to precede even numbers. So boys are considered older and stronger than girls [1987: 34]. Further Warnaen explains that boys have a better position than girls. This is interesting to examine, because in the context of lisung-halu, the role of women seems to dominate. Sundanese recognize and admit the world's top female figure which is called Sunan Ambu. According to Sumardjo, in Sundanese Artifact Symbols of Sundanese Poems, Sunan Ambu is the Mother of Godliness which is worshiped, exalted by Sundanese. Sunan Ambu resides in kahyangan (the world's top). In the cosmological order, kahyangan is the Great Mandala, where Sang Hyang Tunggal is located. Furthermore, Sumardjo explains that Sunan Ambu may be an embodiment of Dewi Sri. However, because in West Java, the worship of Goddess Uma is more dominant, then this Goddess Uma is called Sunan Ambu [2003: 236]

The cosmology concept of Sundanese knows the dualism cosmology. It is a concept of world order on Sundanese that matches two opposing characters (lalaki - awewe, cangkang - eusi, luhur - handap, garing - baseuh). This concept is a representation of two qualities that are smooth and rough. Smooth is a symbol of transcendent qualities (sacred, metaphysical) while its opponent is a symbol of imanent qualities (profane, physical). This concept of world order is reflected in the Sundanese life view of human in relation to the natural environment. This life view is implemented in their attitudes toward things and time. According to Sundanese, nature has two appearances, that is friendly and frightening.

Lisung-alu can not be separated from Sundanese farming customs. In kampung Naga, one of the daily activities of this community, especially mothers, is pounding rice to meet the daily needs of rice. They do it by using lisung-ha$l u$ or jubleg and other additional tools like nyitu to winnow rice. The activity is conducted in a place that is called saung lisung. In kampong Naga, saung lisung (saung lesung) is a stage building above balong (pond) and open 


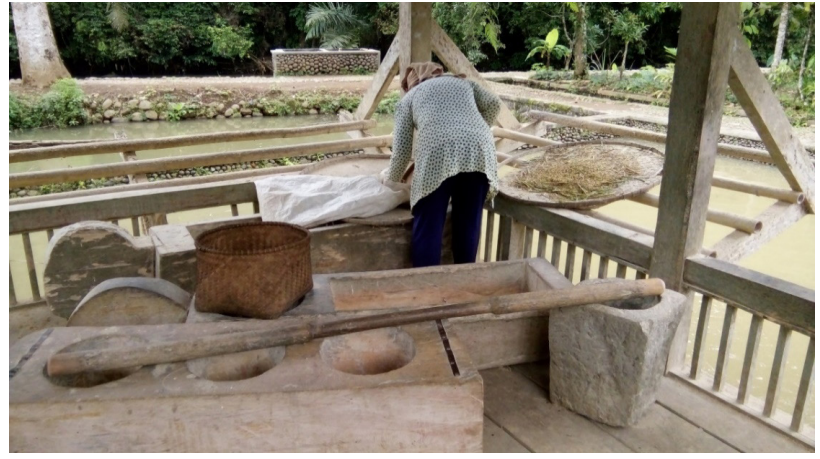

Figure 1. Lisung-halu and jubleg in Saung Lisung Kampung Naga-Tasikmalaya

(Source: Data of Tiara Isfiaty, 2016)

without walls. It is located towards the West side, as shown in Figure 1.

Of all farming activities, planting rice is the most important activity. According to Soeganda, Sundanese have the belief that rice plants are protected by the spirits which are called Nini Kinayan Tani and Aki Kinayan Tani [1982: 153]. In each growing time, rice is believed to have its own guard [pohaci]. It is recorded there are 13 Pohaci which guard and protect the rice plants according to the time of its growth. Agrarian Sundanese also express their respect to rice by calling rice with kersa Nyai which means willingness of wife/woman/mother. They call rice grain with panon, meaning eye, related to the origin of this plant growth. When the rice is harvested and will be pounded, the rice which is placed on lisung, first is recited by incantation. Addressed to Pohaci Lisung namely Sorowong Jati (Jatnika, 2018 : 42) and Pohaci Sanghyang Sri for the pounding of rice pohaci does not run in fear and after grain becomes rice, it will get mercy congratulations. These functions illustrate the values of life and beliefs of Sundanese to many abstract things. It is translated in a certain way which is born from the consciousness of Sundanese, through certain types of artifacts

\section{RESEARCH METHOD}

The focus of the issues which is raised in this article is to describe the meaning that derived from physically form of lisung halu as symbol in world view of Sundanese. They have an orientation on awareness of their origin. Men are considered stronger than women. But in the context of lisung-halu, the role becomes reversed. Lisung-halu is a cultural product which is born from the mythical logic of Sundanese. They are the manifestation of values, norms, characteristics, desires and beliefs of agrarian Sundanese. The personification of male and female in the world's top (the mythical world) The importance of women's role in Sundanese cultural structure can be traced by linking the elements of artifacts as surface culture (constructed by consciousness) to the elements of deep culture, through the personification of women in the world's top (mythical world). This article is descriptive qualitative. It uses psycho-analytical theory from Carl Gustav Jung, which emphasizes the origin of personality and human nature as the hereditary carrier of ancestors on the race. According to Bradshaw and Storm (2013: 154) C.G. Jung proposed that archetypal symbols carry implicit meanings. In the cultural structure, myths are in the unconscious region that related to implicit meanings. So that the psychoanalytic perspective is appropriate to study the physical of lisung-halu (the output of consciousness) as the personification of women in the mythical world (unconscious output) within the framework of the world view of agrarian Sundanese.

The approach which is taken in this article is the cultural approach because this article is an attempt to understand the facts that refer to something which involves the process of interpretative perspective and human experience. To uphold the objectivity of writing, the authors conduct literature studies, observations, interviews and documentation directly in Kampung Naga and Cigugur Village Kuningan West Java, Indonesia. Both locations are chosen because the people in both villages in West Java still hold the tradition of their ancestral hereditary culture. The life of the Naga and Cigugur villagers is a reflection of the inherited and oral heritage value system. This writing is in order to generate the insight and knowledge about the suitability of life values and beliefs of agrarian Sundanese which are contained in lisung-halu through personification of women in mythical world.

\section{THE ANALYSIS AND INTERPRETATION OF ARCHETYPES ELEMENTS ON LISUNG-HA- $L U$ AS THE PERSONIFICATION OF WOM- AN'S MYTHICAL WORLD OF SUNDANESE AGRARIAN SOCIETY}

Based on psychoanalysis, cultural structure can be mapped into two areas, namely the area of the surface culture and the deep culture. The area of the surface culture is the area which is associated with human consciousness. The elements which are contained in this area are visible elements or sensory elements. It includes the elements of artifacts and behavioral. The area of the deep culture is an area which is associated with human unconsciousness. The elements contained in this region are invisible or unintended elements. It includes elements of beliefs, norms, characters, motives, values, and desires. In visual mapping, the position of the surface culture area is above the deep culture area. Psychoanalysis of Carl Gustav Jung emphasizes the origin of personality in race, humans carrying a tendency which is inherited from their ancestors. Jung examines mythology, religion, symbols, ancient rituals, customs and primitive beliefs in search of the roots of personality development. In the book of Four Archetypes, Jung raises the term of mother archetypes as part of the collective unconscious. Etymologically, archetypes are derived from Greek, arche and tuphos. 


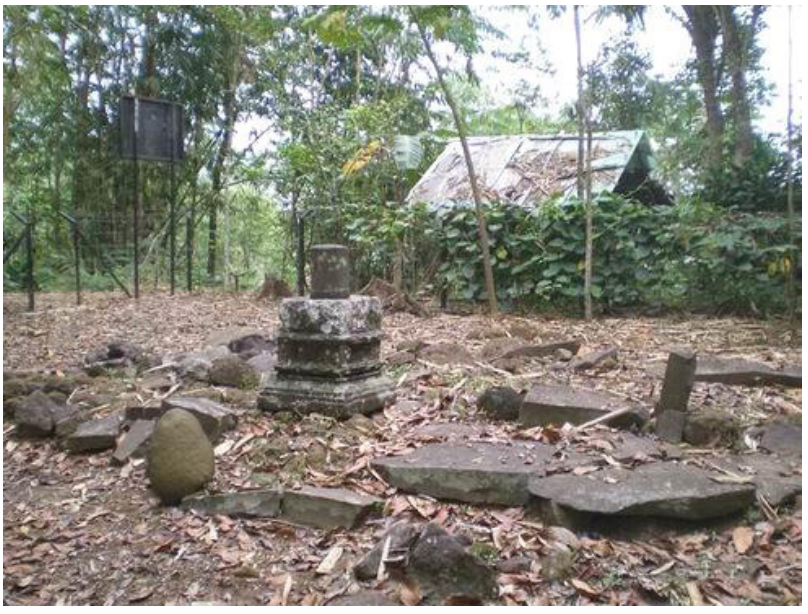

Figure 2. Lingga Yoni Kampung Sindanglengo, Sukamaju Kidul, District Indihiang, Tasikmalaya

(Source: Data of Disparbud West Java, Without Year)

Carl Gustav Jung formulates the collective unconsciousness as a universal element, derived from generations, not individuals. This element is very difficult to realize. The collective unconsciousness contains what he calls the archetypes. The three most important archetypes according to Jung are anima, animus and shadow. Anima is a female archetype in man, animus is a male archetype in woman, and shadow is animalistic archetype or also called the evil side of man. Other archetypes include archetypes of father, mother, child, hero, girl, wise parent, God, and so on. In this study, the discussion of lisung as the personification of women in the world's top in the world view of agrarian Sundanese, will be limited based on the archetype of mother, anima and animus. The archetype of mother is described as the innate abilities that exist in man over all matters relating to the maternal because every human being comes from an environment that involves the mother figure and role. Jung assumes that these innate conditions and abilities can be projected into a clearer world or figure. Even when the reference figure of mother does not exist, humans will still concrete it by personifying archetype on mythical figure. Anima is a female archetype in man. And animus is a male archetype in woman.

Here is a discussion of lisung-halu as the personification of woman in the mythical world in the world view of agrarian sundanese, based on the three elements of achetypes, namely archetypes of mother, anima and animus. First of all, lisung-halu will be discussed as a form of collective unconsciousness. The collective unconsciousness can be described as a great psychological inheritance of human development, which is re-born. As the output of the collective unconsciousness, Lisung-halu is a legacy which is reborn from lingga yoni artifact. In West Java, Lingga Yoni Site is located on Jl. Blok Gunung Kabuyutan, which is administratively included in Wangkelang Block Kampung Sindanglengo, Sukamaju Kidul, Indihiang Sub-district

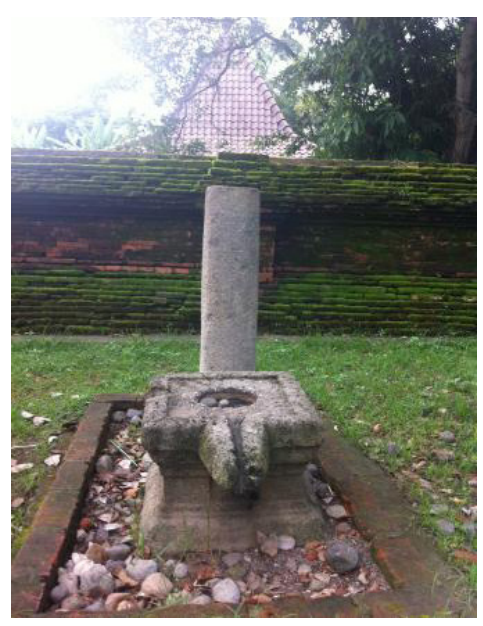

Figure 3. Lingga Yoni in the complex of Sitiinggil Keraton Kasepuhan, Cirebon

(Source: Data of Tiara Isfiaty, 2015)

[figure 2]. The site is about $8 \mathrm{~km}$ from the center of Tasikmalaya City. Lingga Yoni can also be found in the complex of Siti Inggil Keraton Kasepuhan Cirebon [picture 3], presumably a relic of the early era of Islam in Cirebon. Lingga and Yoni are the remains of a classical Hindu-Buddhist in classical culture. Lisung is a representation of yoni [female genitals where the birth of man]. Halu is a representation of lingga [male genitals]. The melting of both is a philosophy of fertility.

In the perspective of the Sundanese world view, lingga symbolizes Bathara Guru. In the Hindu tradition, Bathara Guru is god Shiva, while Yoni symbolizes Goddess Uma. In the Hindu tradition, Goddess Uma is the goddess Parwati, the wife of god Shiva. Both symbolize the unity of the highest or the totality of all that exists. Both figures are present in the tales of Sasakala about "Pare Sok Called Nyi Sri".

Furthermore, in the objectivity interest of insight and knowledge about the values of life and beliefs of the agrarian Sundanese which are embodied in lisung-halu through the personification of woman in the mythical world, below is table 1 The Study Elements of Archetypes In Lisung-Halu As Woman's Personification in The Mythical World of Agrarian Sundanese. The description is done to get the suitability of data in field with result of literature study. 
Table 1. Study on Elements of Archetypes in Lisung-Halu

As a Personification of Women on the Mythcal World of Agrarian Sundanese (Source: Data of Tiara Isfiaty, 2019)

ELEMENT OF AR-

\section{ARCHETIYPES OF} MOTHER

The longing for the mother figure to take care of life
Sunan Ambu is the figure of a divine woman. Being in $k a-$ hyangan where the hyang live. Formulated as the Mother of Devotion worshiped, honored by the old Sundanese. In many Sundanese poems, Sunan Ambu is the goddess of human help, the loving goddess of human suffering. So that the Sundanese consider it a representation on the aspects of life, creation, love and the administration of the cosmos.
The Sundanese awareness of their origins in the context of the archetypes emphasizes the importance of rituals as a tribute to the inhabitants of the mythical world and the pleading of salvation for the next life. This is seen in the implementation of Mapag Sri Dance. This dance becomes the main moment in the celebration of the Great Harvest (Seren Taun) in Cigugur Village. This dance is performed by members of the kingdom, the daughter of the king as the descendants of Prince Madrais (the pioneer of Java Sunda belief which is still held firmly by his descendants and the people of Cigugur Village). Mapag Sri dance performers previously perform fasting as a condition of divine acts on Dewi Sri. This dance is not tied to dance choreography like a normal dance. The dancers' movement is believed to be the result of the union between the dancer and Dewi Sri.
ANIMA

Archetypes of female in man
Nini Kinayan Tani and Aki Kinayan Tani. Both are spirits who are in charge of protecting the seeds of planted rice.

Goddess Uma and Bathara Guru. Both symbolize the unity of the highest or the totality of all that exists.

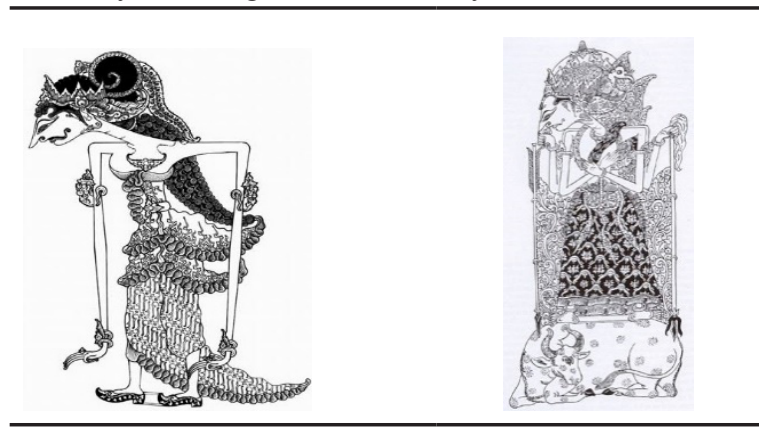

Figure 5. Goddess Uma (left) wife of Bathara Guru (right)
Can be formulated as the feminine side of God. Hindu-Buddhist traditions recognize the term magic (power, might, protection or energy) embodied as the goddess of the gods' mate. Wife is a source of strength, creative resources of their partners' power.

The concept of Sundanese dualism cosmology in the context of archetypes, does not contradict the two attributes of men and women. What happens is that both shifts are united so there is harmony and balance.

(Source: Disparbud of West Java, Without Year) 


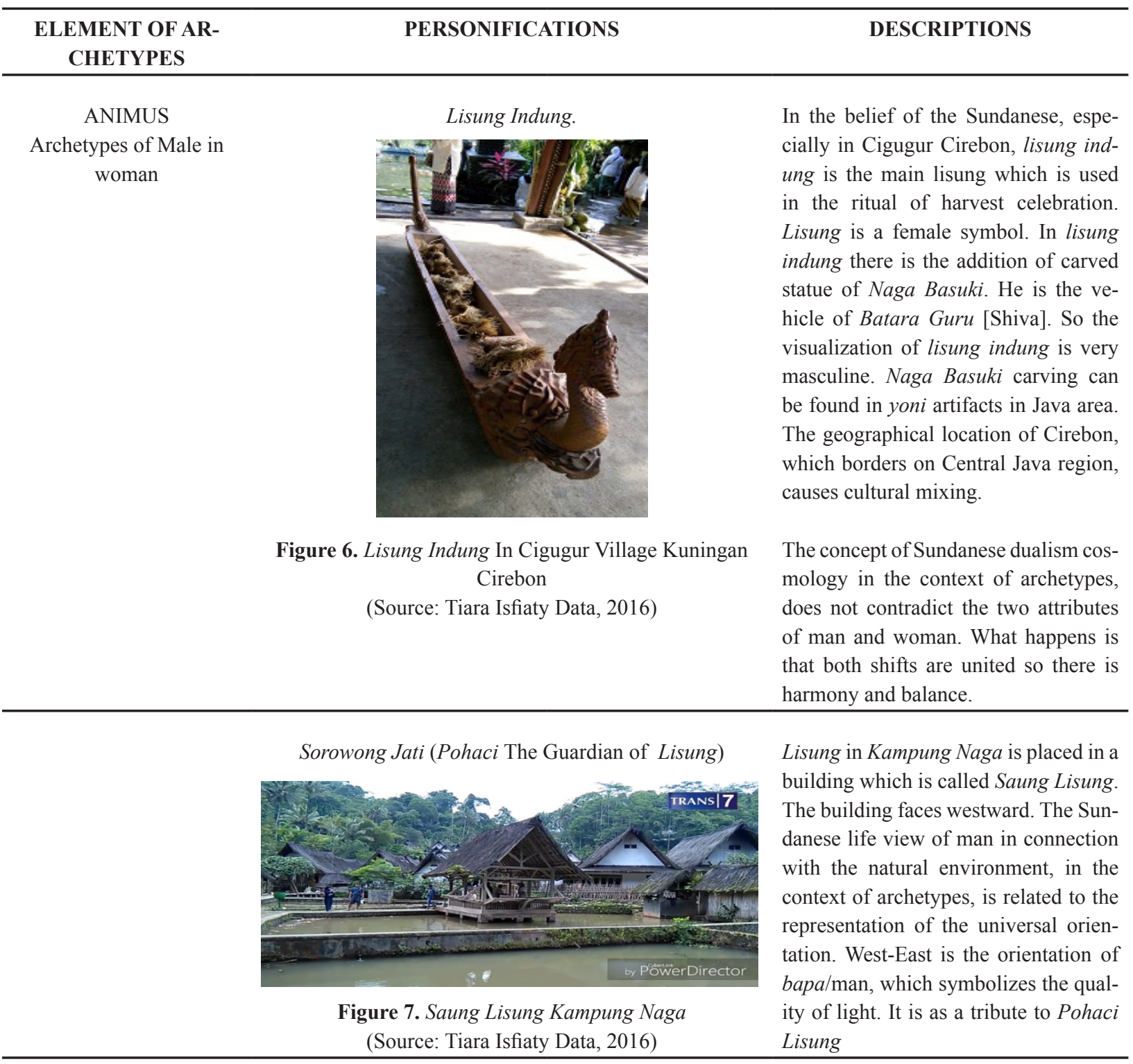

Furthermore, as a final discussion, it will be conducted linking lisung-halu as a women's personification of mythical world based on three elements of archetypes. All of them refer to the world view of agrarian Sundanese. The relationship of matching exposure of these four variables is expected to answer the intention of writing the article. That is, it produces insight and knowledge about the conformity of life values and beliefs of agrarian Sundanese that is embodied in lisung-halu through personification of women on the mythical world. The study of the relevance on its relation can be seen in table 2 Relation between Elements of Archetypes, Lisung-Halu, Personification and World View of Sundanese. 
Table 2 Relation between Archetypes Elements, Lisung-Halu, Personification and World View of Sundanese (Source: Data of Tiara Isfiaty, 2019)

\begin{tabular}{|c|c|c|c|}
\hline $\begin{array}{l}\text { ELEMENT OF AR- } \\
\text { CHETYPES } \\
\end{array}$ & ARTIFACTS & PERSONIFICATION & $\begin{array}{c}\text { WORLD VIEW OF } \\
\text { AGRARIAN SUNDANESE }\end{array}$ \\
\hline $\begin{array}{l}\text { MOTHER ARCHE- } \\
\text { TYPES } \\
\text { The longing for the } \\
\text { mother figure to take } \\
\text { care of life }\end{array}$ & $\begin{array}{l}\text { LISUNG } \\
\text { The Symbol of } \\
\text { Woman }\end{array}$ & $\begin{array}{c}\text { Sunan Ambu } \\
\text { is associated with Mapag Sri } \\
\text { Dance Ritual In Seren Taun } \\
\text { Celebration in Cigugur Village } \\
\text { Kuningan }\end{array}$ & $\begin{array}{l}\text { The Sundanese awareness their } \\
\text { origin } \\
\text { The Sundanese life view of human } \\
\text { life in relation to the natural envi- } \\
\text { ronment }\end{array}$ \\
\hline \multirow{3}{*}{$\begin{array}{l}\text { ANIMA } \\
\text { archetypes of female } \\
\text { in man }\end{array}$} & $\begin{array}{c}H A L U \\
\text { The Symbol of Man }\end{array}$ & $\begin{array}{c}\text { Nini Kinayan Tani and Aki } \\
\text { Kinayan Tani. }\end{array}$ & $\begin{array}{c}\text { The Sundanese awareness of their } \\
\text { origin }\end{array}$ \\
\hline & & $\begin{array}{l}\text { Goddess Uma and Bathara } \\
\text { Guru. }\end{array}$ & $\begin{array}{c}\text { The Sundanese life view of human } \\
\text { life in relation to the natural envi- } \\
\text { ronment }\end{array}$ \\
\hline & & & $\begin{array}{l}\text { Dualism Cosmology, namely the } \\
\text { concept of world order of Sundanese } \\
\text { who match two opposite characters. } \\
\text { This concept is a representation of } \\
\text { two qualities }\end{array}$ \\
\hline $\begin{array}{l}\text { ANIMUS } \\
\text { archetypes of male in } \\
\text { woman }\end{array}$ & $\begin{array}{l}\text { LISUNG } \\
\text { The Symbol of } \\
\text { Woman }\end{array}$ & $\begin{array}{l}\text { Lisung Indung. } \\
\text { Sorowong Jati (Pohaci, The } \\
\text { Guardian of Lisung) is associat- } \\
\text { ed with the orientation of Saung } \\
\text { Lisung direction in Kampung } \\
\text { Naga }\end{array}$ & $\begin{array}{c}\text { The Sundanese awareness of their } \\
\text { origin } \\
\text { The Sundanese life view of human } \\
\text { life in relation to the natural envi- } \\
\text { ronment } \\
\text { Dualism Cosmology, namely the } \\
\text { concept of world order of Sundanese } \\
\text { who match two opposite characters. } \\
\text { This concept is a representation of } \\
\text { two qualities }\end{array}$ \\
\hline
\end{tabular}

\section{CONCLUSION}

In cultural structures, deep culture area is the area that is dominating and constructing every joint of cultural life actors. So that the psychoanalytic perspective, especially the Jungian archetypes element is capable of producing the novelty on the point of view as well as the precision in digging the values of local wisdom and knowledge. The result of a very interesting discussion is the finding of Sundanese world view about dualism cosmology. The concept of a world order that matches these two opposing characters is present not to be contradicted. What happens is that both attributes are the representations of two different qualities. They are united so that there is harmony and balance. This is probably which is called binary concept of Eastern society. Sundanese cultural artifacts physically very expose the natural character. This is a form of closeness and respect for nature. So, the world view of the view of Sundanese life about human beings in relation to the natural environment is the basis of the personification in woman form. Nature teaches reciprocal relationships that prioritize love, affection and caring attitude. All of them become the basic characteristics of a Sundanese mother embodiment. It is born from the logic of myth (in the unconscious area) and is present as a role model in meaning of life. World view of Sundanese Awareness will be their origin, in this article, it holds an important position. This awareness is the quality of Sundanese inner concept. That makes it able to preserve the values of life, wisdom and conviction, the inheritance of its ancestors, and pass it on from generation to generation 


\section{REFERENCE}

Darpan (2013), Kompendium Istilah Sistem Pertanian Tradisional Sunda/Compendium The terms of Sundanese Traditional Agricultural Systems, Pustaka Jaya. Bandung

Isfiaty, Tiara (2016) "Representasi Kosmologi Dualisme Pada Rumah Adat Sunda Sebagai Nilai Kearifan Tempatan (Kajian Kes : Bumi Adat - Kampung Adat Cikondang - Pangalengan, Bandung)"'/"Representation of Dualism Cosmology at Sundanese Indigenous House as Value of Placement Wisdom (Study of Case: Indigenous Earth Kampung Adat Cikondang - Pangalengan, Bandung)". Prosiding 6th International Conference on Local Knowledge 27th - 28th July 2016 St Giles Wembley, Pulau Pinang, Malaysia

Jung, C G (1970) Translated by R F C Hull. Four Archetypes Mother Rebirth Spirit Trickster. Princeton, Uniersity Press.

Khairunnisa, Meta (2014), "Kosmologi Ruang Adat Sebagai Identitas Pemukiman Kampung Naga, Tasikmalaya - Jawa Barat"/ "Cosmology of Indigenous Space as the Identity of Kampung Naga Settlement, Tasikmalaya - West Java" diunduh tanggal 5 Agustus 2017 dari http://ejournal.undip.ac.id/index.php/teknik/ volume 35 (1)

Mufrihah, Dwi Zahrotul (Mei 2018), “Fungsi Dan Makna Simbolik Kesenian Jaranan Jur Ngasinan Desa Sukorejo Kecamatan Sutojayan Kabupaten Blitar" MUDRA Jurnal Seni Budaya diunduh tanggal 20 Januari 2020 dari https:// jurnal.isi-dps.ac.id/index.php/mudra/article/view/337/206 / volume 33, Nomor 2

Sumardjo, Jakob (2003), Simbol-Simbol Artefak Budaya SUnda Tafsir-Tafsir Pantun Sunda/The Symbols of Sundanese Cultural Artifacts The Commentation of Sundanese Poem, Kelir, Bandung

Soeganda, Prawira (198), Upacara Adat Di Pasundan/ Traditional Ceremony In Pasundan. Sumur Bandung, Bandung

Sally Bradshaw and Lance Storm (Sep 2013), "Archetypes, symbols and the apprehension of meaning" International Journal of Jungian Studies diunduh tanggal 20 Januari 2020 dari https://www.tandfonline.com/doi/ full/10.1080/19409052.2012.685662?src=recsys /volume $3 / 2013 /$ issue 2

Warnaen, Suwarsih et al. (1987), Pandangan Hidup Orang Sunda Seperti Tercermin Dalam Tradisi Lisan Dan Sastra Sunda/The Sundanese Life View As Reflected In Oral Tradition And Sundanese Literature. Bandung: Ministry of Education and Culture, Directorate General of Culture, Research and Study Section of Sundanese Culture.
Wessing, Robert (1974), "Cosmology And Social Behaviour In West Javanese Settlement” Thesis for degree of Doctor Philosophy In Antrophology of the University of Illinois at Urbana-Champaign.

Qodariah, Lelly dan Laely Armiyati (May 2013).."NilaiNilai Kearifan Lokal Masyarakat Adat Kampung Naga sebagai Alternatif Sumber Belajar"/"The Local Wisdom Values of Indigenous People at Kampung Naga as an Alternative to Learning Resources". SOCIA Journal of Social Sciences May 2013, Vol. 10, No. 1 page 10 - 20, 2013 